\title{
THE DISCOVERY OF A GLADIATORIAL SCHOOL AT CARNUNTUM
}

\author{
W. Neubauer, S. Seren, A. Hinterleitner, M. Doneus, K. Löcker, I. Trinks, \\ E. Nau, M. Pregesbauer, M. Kucera, G. Verhoeven
}

The Roman town of Carnuntum is located on the southern bank of the Danube River $40 \mathrm{~km}$ southeast of Vienna, at the former border of the Roman Empire. The landscape is characterised by the river cutting through the foothills of the Carpathian mountain ridge to the east and is situated on gravel terraces forming a flat to slightly hilly terrain. As the Roman capital of the province Pannonia, Carnuntum was an important town during the first four centuries AD. Roman Carnuntum consisted of a large legionary camp with associated auxiliary camps and an extended surrounding civilian settlement, the so-called canabae legionis, in the eastern part. The western part was dominated by the civil town, the autonomous municipium Aelium Karnuntum raised to this status by Caesar Hadrian in 124 AD.

Today, the archaeological remains are spread over an area of approximately $10 \mathrm{~km}^{2}$ within the modern communities of Bad Deutsch Altenburg and Petronell. For more than 15 years, this archaeological landscape has been the focus of a large-scale archaeological prospection project (Neubauer et al., 2012) applying and developing the latest non-invasive remote sensing and geophysical near-surface prospection methods and technologies. This project was initiated by the team ZAMG Archeo Prospections ${ }^{\circledR}$ and the University of Vienna (Doneus et al., 2001; Doneus and Neubauer, 2005; Eder-Hinterleitner et al., 2003) and continued in 2010 by the Ludwig Boltzmann Institute for Archaeological Prospection and Virtual Archaeology (LBI ArchPro). Only a few monuments from the Roman period survive as above-ground monuments, such as the Heathen's Gate, an originally $15 \mathrm{~m}$ high quadrifons. Some remains are still visible in the topography, such as the western of the two known amphitheatres at Carnuntum.

The western amphitheatre south of the civil town was erected outside of the Roman Civil Town in the first half of the

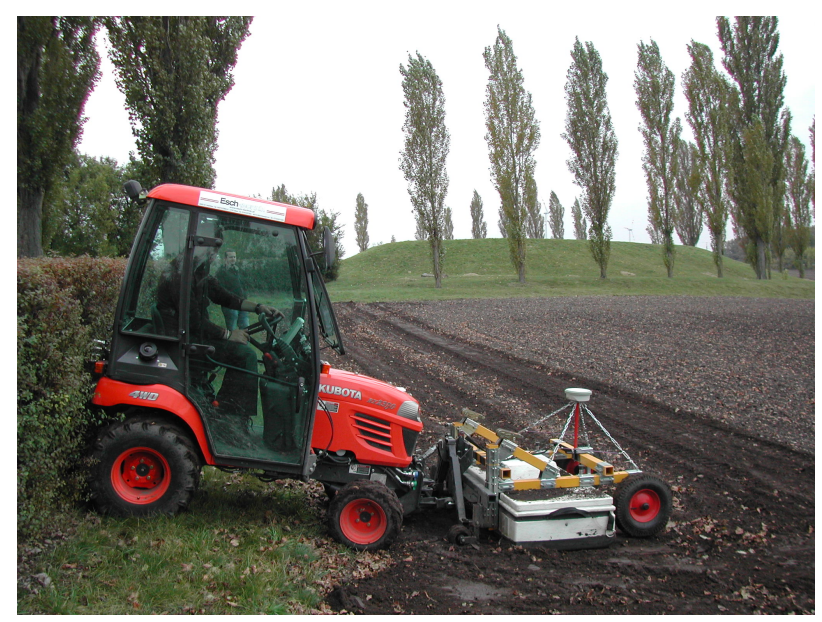

Figure 1: The 16-channel 400 MHz MALA Imaging Radar Array surveying the field containing the school of gladiators. In the background some of the remains of Carnuntum's western amphitheatre can be seen.

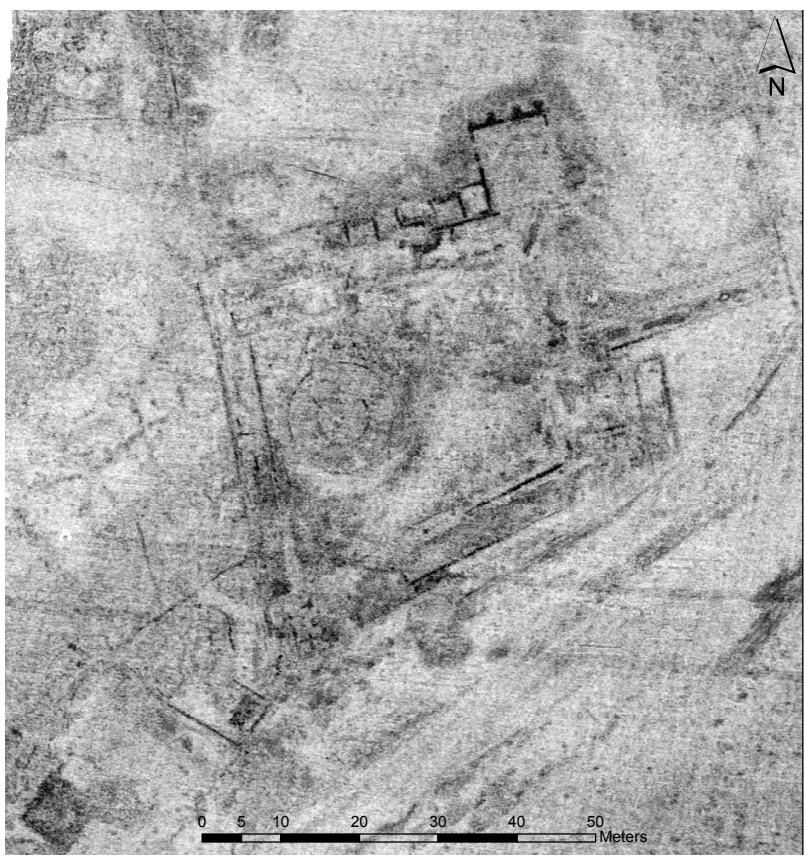

Figure 2: GPR depth-slice of the high-definition GPR data acquired with the MIRA system from ca. $60 \mathrm{~cm}$ depth. Note the point-anomaly belonging to the pole that pressumably had been been placed in the centre of the training arena.

second century AD and was modified many times during later phases, as excavations in 1923-1930 showed. The Roman amphitheatre, hosting up to 13,000 spectators, was credited by contemporary inscriptions to have been the fourth largest amphitheatre in the Roman Empire. It was intensively used for gladiatorial games, as documented and illustrated by many finds. Despite the earlier excavations, the surroundings of the amphitheatre were mostly terra incognita. First indications on significant structures around the amphitheatre came from aerial photographs showing a main Roman road leading towards it from the town, with shops and tabernas towards its eastern side. In the west, however, no structures at all were visible.

In September 2011, the LBI ArchPro and its international partner consortium announced the discovery of a gladiatorial school (Latin ludus) west of the amphitheatre. This unique discovery, rated amongst the top-ten archaeological discoveries of 2011 [1, was made possible by systematically applying a multidisciplinary prospection approach based on remote sensing and high-resolution near-surface geophysical prospection during the last decade (Neubauer, 2011; Neubauer et al., 2012).

Repeated aerial reconnaissance flights over Carnuntum in the 1990s vaguely indicated buildings west of the amphithe-

\footnotetext{
${ }^{1}$ http://archive.archaeology.org/1201/features/topten_austria.html (accessed 28.3.2013)
} 

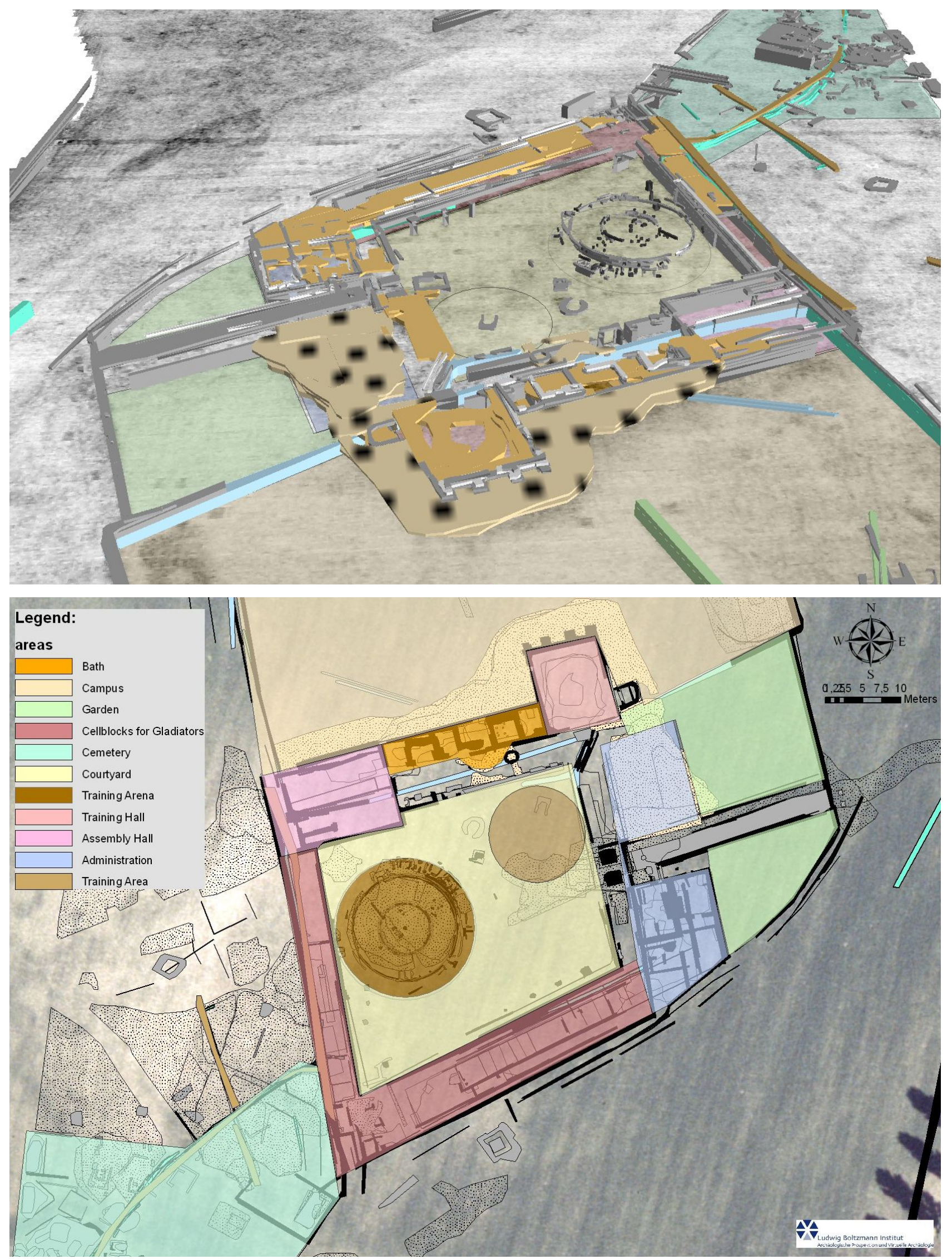

Figure 3: 3D interpretation of the magnetic and GPR prospection data (top) and plan view presentation (bottom). 
atre, based on a large anomaly consistently showing up as soil and crop marks. In 2000, a magnetic survey using a manually operated five sensor PICODAS MEP750 Caesium magnetometer was carried out in the respective field to verify these findings. The magnetometer data, sampled with a spatial resolution of $12.5 \times 50 \mathrm{~cm}$, revealed traces of the foundation walls of a large trapezoidal building complex, as well as associated infrastructure, such as a main canal belonging to the water supply system of the Roman town. A subsequent ground penetrating radar (GPR) survey conducted in 2000 using a Sensors \& Software PulseEkko ${ }^{\text {Pro }} 900 \mathrm{MHz}$ antenna manually towed in a sledge with $5 \mathrm{~cm}$ inline GPR trace spacing and $50 \mathrm{~cm}$ cross line spacing resulted in GPR depth-slices showing more details of the large building complex. Animations of the depth-slices revealed circular structures in the building's courtyard and indicated an uncommon function of the large complex.

Recent technological and methodological developments leading to increased efficiency of near-surface magnetometry, GPR, electromagnetic induction surveying, airborne imaging spectroscopy and laser scanning formed the background for an additional integrated investigation of the area by an international team of archaeologists, geophysicists, soil scientists and IT experts from the LBI ArchPro and its international partners. In spring 2011, the team started with a high-definition GPR survey of the school of gladiators using a MALA Imaging Radar Array (MIRA) system in motorized configuration (Figure 1). The array consists of $16 \times 400 \mathrm{MHz}$ antennae with $8 \mathrm{~cm}$ channel spacing and possibilities for 4 or $8 \mathrm{~cm}$ inline GPR trace spacing using a trace stacking factor of 4 and operation speeds of $12-15 \mathrm{~km} / \mathrm{h}$ (Trinks et al., 2010). Using a real-time kinematic GPS with centimetre accuracy at data rates of $5 \mathrm{~Hz}$ or more and smart navigation solutions, the acquisition of $3 \mathrm{D}$ archaeological prospection data volumes has become possible, imaging buried Roman structures in unprecedented resolution. The measured GPR data were processed into depth-slice images (Figure 2) using special software developed in close collaboration with ZAMG Archeo Prospections ${ }^{\circledR}$. Subsequently, the new GPR results have been complemented with magnetometer data acquired using a novel motorized 10-sensor Foerster fluxgate gradiometer array, extending the initial Caesium magnetometer survey area. In collaboration with the research group ORBit at Ghent University, highresolution electromagnetic induction (EMI) data were acquired in autumn 2011 using a novel motorized four-coil DualEM$21 \mathrm{~S}$ sensor. The EMI data provided complementary information about the magnetic susceptibility and electrical conductivity of soil volumes with different depth extent.

All geophysical measurement devices were equipped with the latest differential GPS technology permitting exact geopositioning of the measurements. Since GPS readings were stored five times per second with an accuracy of approximately $2 \mathrm{~cm}$, data collection could be performed at speeds between 8 and $30 \mathrm{~km} / \mathrm{h}$. The integration of the individual survey methods in combination with a detailed digital terrain model obtained through airborne laser scanning puts the discovered Roman remains in context with their topographic position and the associated infrastructure and environmental settings. Combining all data permitted an integrated GIS-based site analysis of the revealed archaeological stratification in relation to the underlying geology, the hydrological settings and the geomorphological situation considering the palaeorelief and the pedological context.

The detailed geophysical and archaeological interpretation of the data (Figure 3 ) resulted in a 3D interpretation model of the detected remains of the ludus. The outstandingly well-preserved architecture was revealed through virtual excavation within an integrated 3D data volume produced by high-resolution, nondestructive prospection methods. The foundations of the building complex including a circular training arena surrounded by basements of former wooden stands, cell blocks, training and assembly halls, infrastructure, practice fields, a bath complex and an administrative wing were mapped in three dimensions in unprecedented detail and virtually reconstructed (Figure 4). The completeness of preservation of this gladiatorial school at Carnuntum is considered to be unique in the former Roman Empire.

The main building complex of the ludus at Carnuntum covers $2,800 \mathrm{~m}^{2}$ located within a walled parcel of about $11,000 \mathrm{~m}^{2}$ just outside of the Roman town. The main buildings at the southeastern end of the parcel are arranged around a central inner courtyard. A single, easily controlled entrance to the complex can be seen on its eastern side, facing the amphitheatre. Inside the school's courtyard, the separate circular training arena in which the gladiators practiced, $19 \mathrm{~m}$ in diameter, was surrounded by wooden spectator stands founded on stone basements. In the centre of this arena clear evidence for the foundation of the palus, a wooden pole used to exercise blows with the sword and body slams with the shield (Futrell, 2006), was recorded.The importance of this pole can also be deduced from the names given to the best gladiators: primus palus, secundus palus etc. (Futrell, 2006; Mejer, 2007). A building complex including a $100 \mathrm{~m}^{2}$ heated training hall, an extensive bathing complex and an assembly hall has been identified around the closed courtyard. The gladiators were accommodated in small cells of approx. $5 \mathrm{~m}^{2}$, arranged within an elongated cell block. The administrative wing and living quarters of the school's owner, the lanista (Bomgardner, 2000; Meijer, 2007) can clearly be discerned in the prospection data to the right and left of the main entrance of the ludus. The barracks of the school and the lanista's buildings were at least two stories high, as indicated by typical stairway corridors. The lanista was head of his familia gladiatoria with all legal power over the life and death of the gladiators.

To the northwest, and within the walled compound, an extended open campus adjoins the school, which most likely held further practice areas for chariot races, stables and enclosures for wild animals. The animals - remains of bears and lions were found inside the amphitheatre - were put into the arena together with specialized venationes, the beast hunting and bestiarii, the beast fighting gladiators. In the immediate vicinity of the ludus, distinctly separated from other burial fields of Carnuntum, the separate cemetery of the gladiators was discovered. We are convinced that we found the cemetery of the gladiators' right behind the building, with large burial monuments, stone sarcophaguses and other more simple graves.

Aside from foundation walls of the main building complex and the enclosed campus, the geophysical prospection data revealed a major part of the public water and drainage network, hypocaust floor-heating systems, portals, the foundations of memorials, paths and gateways. Given its state of preservation, dimensions and type of architecture, the discovered ludus is considered to be internationally unique. Although it is estimated that over one hundred ludi must have been built throughout Roman history (Meijer, 2007), most of them have been destroyed or covered over. The only known existing building directly comparable to the find made in Carnuntum is the partly excavated Ludus Magnus behind the Coliseum (Amphitheatrum Flavium) in Rome (Colini, 1962). Unlike the new discovery, the Ludus Magnus is only partly accessible today and fewer details have been preserved.

This unique archaeological find exemplifies the tremendous amount of highly-detailed information that can be gathered by 


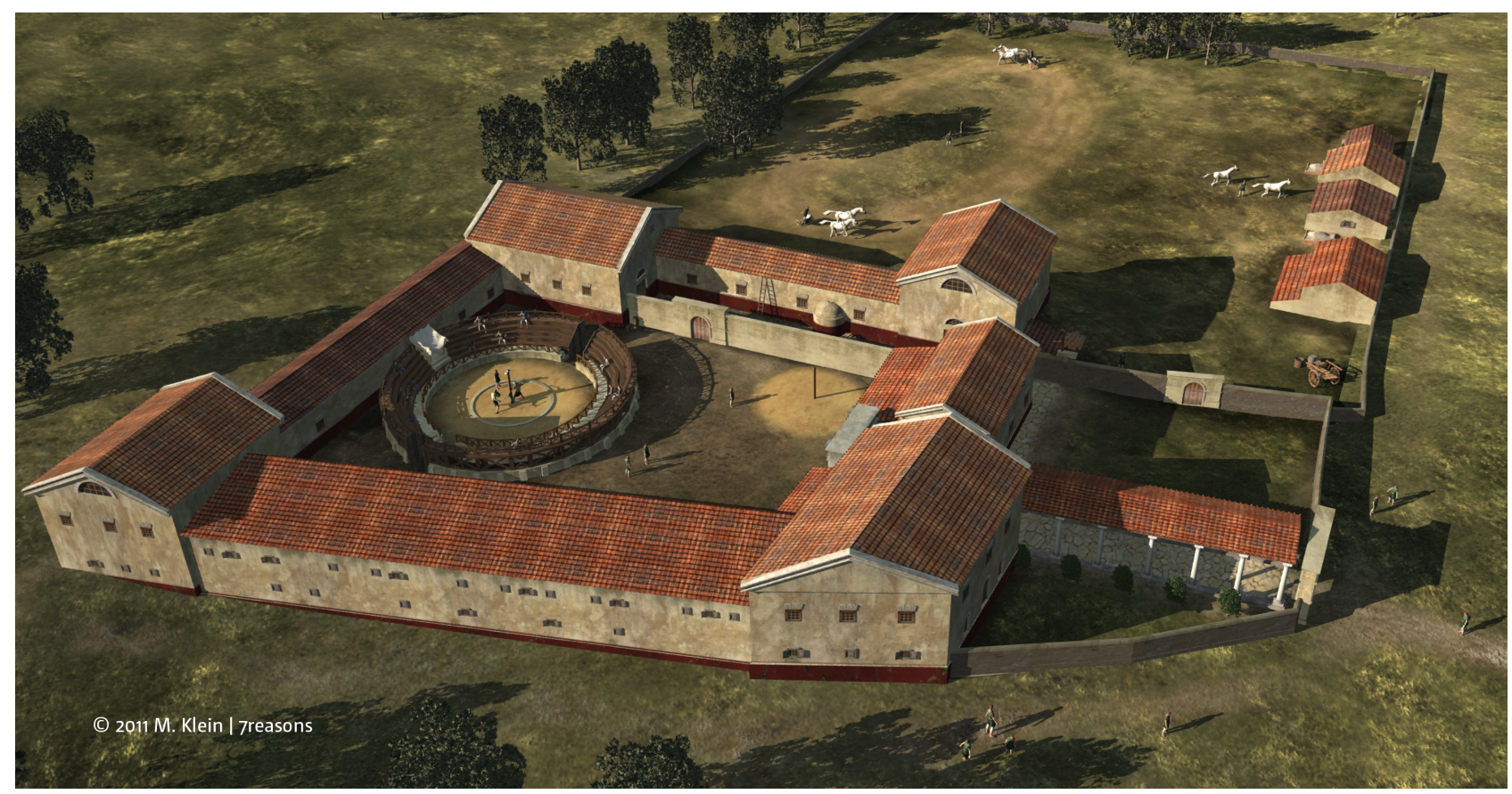

Figure 4: Virtual reconstruction of the school of gladiators. (C) M. Klein I 7reasons

following the latest multidisciplinary, entirely non-invasive and hence archaeologically sustainable, non-destructive, prospection approach promoted by the LBI ArchPro. During the $19^{\text {th }}$ century, Carnuntum was called the "Pompeii at the doors of Vienna" due to the good preservation of the Roman ruins. Since then, the situation has changed drastically. Both aerial photography and geophysical data show that the archaeological heritage has suffered severe damage.

The presented case study exemplifies a long-term interdisciplinary archaeological prospection approach to the survey of Roman archaeological landscapes, initially presented at the Archaeological Prospection Conference 2001 (Doneus et al., 2001; Doneus and Neubauer, 2005). Invoked by the discovery of the ludus, the archaeological landscape Carnuntum will now be mapped in a large-scale prospection project over the next three years, directed by the LBI ArchPro. Through the combination of aerial archaeology and modern remote sensing with highresolution geophysical subsurface mapping and a GIS-based archaeological interpretation and spatial analysis, the project will develop a foundation for sustainable cultural heritage management.

\section{REFERENCES}

BOMGARDNER DL. 2000. The Story of the Roman Amphitheatre. London: Routledge.

COLINI AM, COZZA L. 1962. Ludus Magnus. Rome: Monte dei paschi di Siena.

DONEUS M, EDER-HINTERLEITNER A,NEUBAUER W. 2001. Roman Carnuntum - Prospecting the largest archaeological landscape in Austria. In Doneus M, Eder-Hinterleitner A, Neubauer W. (eds) Archaeological Prospection, $4^{\text {th }}$ Inter- national Conference on Archaeological Prospection: 47-59. Vienna: Austrian Academy of Sciences Press.

DONEUS M, NEUBAUER W. 2005. Multiple survey techniques at Roman Carnuntum. Integrated prospection of the largest archaeological landscape in Austria, In: Musson C, Palmer R, Campana S. (eds) In volo nel passato. Aerofotografia e cartografia archeologica: 272-279. Siena: Biblioteca del Dipartimento di Archeologia e Storia delle Arti.

EDER-HINTERLEITNER A, MELICHAR P, NEUBAUER W, DONEUS M, SEREN S. 2003. The city map of ancient Carnuntum - combining archaeological prospection, photogrammetry and GIS. Archaeologia Polona 41: $156-157$.

FUTRELL A. 2006. The Roman games: A sourcebook. Oxford: Blackwell.

MEIJER F. 2007. The Gladiators: History's Most Deadly Sport. New York: St. Martin's Griffin.

NEUBAUER W. 2011. Archäologische Prospektion der Landschaft Carnuntum. In: Carnuntum und Limes. Denkmalpflege in Niederösterreich 45: 23-26.

NEUBAUER W, DONEUS M, TRINKS I, VERHOEVEN G, HINTERLEITNER A, SEREN S, LÖCKER K. 2012. Long-term integrated archaeological prospection at the Roman Town of Carnuntum/Austria. In Johnson P, Millett M. (eds), Archaeological Survey and the City. University of Cambridge Museum of Classical Archaeology Monograph Series No. 3. Oxford: Oxbow: 202-221.

TRINKS I, JOHANSSON B, GUSTAFSSON J, EMILSSON J, FRIBORG J, GUSTAFSSON C, NISSEN J, HINTERLEITNER A. 2010. Efficient, large-scale archaeological prospection using a true three-dimensional ground-penetrating radar array system. Archaeological Prospection 17: 175-186. 